\title{
Judging Judges: The Effect of Courtroom Ceremony on Participant Evaluation of Process Fairness-Related Factors
}

\section{Oscar G. Chase \& Jonathan Thong*}

In this Essay, we describe a study of the effects of ceremonial aspects of litigation on law student evaluation of a moot court oral argument exercise. That begs the question: why study the ceremonial practices of courts? Those practices seem on their face to have little relationship to the traditional proceduralist concerns of accuracy, efficiency, cost, and integrity. In our view, however, judicial ceremony has been understudied and underappreciated as a source of (or barrier to) the legitimacy of judicial institutions. Students of the social psychology of procedural justice have empirical support for the claim that litigant evaluation of a legal process is based in part on their assessments of procedures, and is to some extent independent of their evaluation of outcome fairness. Procedures judged to be fair by litigants have been found to increase compliance with adverse judgments and respect for the rule of law. It is a plausible-but until now unexamined-hypothesis that the ceremonial formality of court processes contributes to a positive evaluation of the process.

Ceremonial practices common in American courtrooms have hardly been without controversy. In one of the most important critical treatments of judicial ceremony, the late American federal judge Jerome Frank mentioned three possible general effects, focusing on the judicial robe. ${ }^{1}$

\footnotetext{
* Oscar G. Chase is the Russell D. Niles Professor of Law at the New York University School of Law and the Co-Faculty Director of the Dwight D. Opperman Institute of Judicial Administration. Jonathan Thong is a Lecturer at the University of Sydney Business School. We gratefully acknowledge the generous financial support of the Filomen D'Agostino and Max E. Greenberg Research Fund of the New York University School of Law. We are grateful to our research assistants Alexandra W. Fields and Jonathan Thorne and to the colleagues who graciously commented on drafts of this Essay, Jerome Bruner, David W. Garland, Rohini Luthra, Geoffrey P. Miller, Daniel Rubinfeld, and Judith Resnik. We are especially grateful to Peggy Cooper Davis, Sandra Scott, and Anh Bui for their invaluable assistance to our study of the NYU School of Law Lawyering Course and to Dean Richard Revesz for his welcome support of empirical scholarship.

1. Jerome Frank, The Cult of the Robe, in COURTS ON TRIAL: MYTH AND REALITY IN AMERICAN JUSTICE 254 (1949).
} 
(He tellingly called his essay "The Cult of the Robe.") First, the robe could enhance the prestige of the judge and, hence, respect for the judicial process. He cites Pascal to the effect that "august apparel" is necessary to promote respect for judicial decisions. In the same vein, uniform appearance of the judges could promote the idea that justice is itself "uniform," which also might increase respect for the "rule of law." Second, the robe could be a "harmless relic" that has no impact on anyone and is worn just as a matter of tradition. Finally, it could create "disquiet" in lawyers, litigants, and witnesses, which would reduce their satisfaction with the experience and interfere with efficient and accurate fact finding. Frank endorses the last point, mentioning with favor the few judges who do not wear robes in court and urging that the robe be abolished. His only evidence for the proposition that robes are harmful is anecdotal. Though Frank wrote over half a century ago, none of his hypotheses have been studied empirically.

Jerome Frank's negative assessment of judicial ceremony was apparently shared by former Supreme Court Chief Justice Warren Burger, who opined that " $[\mathrm{t}] \mathrm{he}$ notion that ordinary people want black-robed judges, well-dressed lawyers, and fine paneled courtrooms as the setting to resolve their disputes is not correct. People with problems, like people with pain, want relief, and they want it as quickly and inexpensively as possible." But that view is not universally shared. According to one contemporary student of the Supreme Court, Christopher Tomlins, the ritualistic conventions of the Supreme Court, such as the dignified black robes and the imposing marble columns, are in fact and by design associated with a sense of authoritative and unbiased justice. ${ }^{3}$ Said Tomlins, later,

Those kinds of appearances are not simply the ephemera that accompanies what the court really does-hears arguments, makes decisions, writes opinions-they are important in their own right . .. I think it is fairly safe to assume that the Chief Justice and the Associate Justices realize that how they appear is of some considerable importance to how they are perceived and, consequently, to the authority that they wield. ${ }^{4}$

2. Warren E. Burger, Our Vicious Legal Spiral, 16 JUDGES J. 23, 49 (1977).

3. Christopher Tomlins, Characterizing the Supreme Court, Introduction to THE UNITED STATES SUPREME COURT: THE PURSUIT OF JUSTICE at xi, xiii (Christopher Tomlins ed., 2005) [hereinafter UNITED STATES SUPREME COURT]; see Katherine Fischer Taylor, First Appearances: The Material Setting and Culture of the Early Supreme Court, in UNITED STATES SUPREME COURT, supra, at 357, 362-64.

4. Christopher Tomlins, Pursuing Justice, Cultivating Power: The Evolving Role of the Supreme Court in the American Polity, 17 RESEARCHING L., no. 1, 2006, at 1, 8; see also OSCAR G. CHASE,

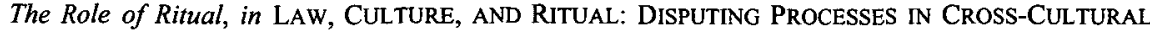
CONTEXT, 114 (2005) (describing the role of ritual in diverse disputing institutions); Antoine Garapon, 
There may be truth in both views. People with disputes may want "relief" as Chief Justice Burger suggested, but the degree to which they actually feel relieved is affected by attributes of the proceeding through which their dispute has been addressed. ${ }^{5}$

The study of courtroom ritual and its effects is not only a matter of theoretical interest. Learning about the effects of courtroom ceremony can lead to improvements in both judicial proceedings and alternative dispute resolution processes. For example, there are differences of opinion among designers of ADR programs about whether court-annexed processes such as arbitration and mediation should use ceremonies similar to those used in courts or should be more informal. Furthermore, some judges eschew courtroom formality and do not wear robes because they believe it inhibits the search for truth and is off-putting for participants. Moreover, when new courts are constituted, either because of profound regime change (as in South Africa, where the Constitutional Court was created after the fall of apartheid) or because of the growing need for new transnational tribunals (such as the International Criminal Court), the design of ceremony is unavoidably confronted. Finally, and especially important, is the hypothesized contribution of judicial ceremony to litigant and public confidence in courts. Tyler and Lind ${ }^{6}$ and Thibault and Walker ${ }^{7}$ have found that assessments of the fairness of procedures are linked to peoples' endorsement of the legal system in general. In sum, we need to learn whether judicial ceremony enhances assessments of the adjudicative process.

\section{DEFINING CEREMONY}

An assessment of the effect of ceremony requires a definition. What kinds of practices count as "ceremonial"? The question is not easily answered, because while one can theoretically divide practices into the ceremonial on one hand, and the "instrumental" on the other, the boundary between the two is not clear. Many ceremonies, after all, are intended to serve some purpose and, in that sense, are also instrumental. ${ }^{8}$

La Robe Judicaire, in BIEN JUGER, ESSAI SUR LE RITUEL JUDICAIRE 71 (1997) (exploring the legitimizing power of ritual vestments in the courts of France).

5. See, e.g., E. Allan Lind et al., In the Eye of the Beholder: Tort Litigants' Evaluations of Their Experiences in the Civil Justice System, 24 L. \& SOC'Y REV. 953 (1990).

6. See Tom R. Tyler \& E. Allan Lind, Procedural Justice, in HANDBOOK OF JUSTICE RESEARCH IN LAW 65 (Joseph Sanders \& V. Lee Hamilton eds., 2001).

7. See John Thibault \& Laurens Walker, Procedural Justice: A Psychological ANALYSIS (1975).

8. Sally F. Moore \& Barbara G. Myerhoff, Secular Ritual: Forms and Meanings, Introduction to Secular Ritual 3, 15 (Sally Falk Moore \& Barbara G. Myerhoff eds., 1977) (describing the difficulty of making a "radical separation" between rituals and instrumental behavior and noting that "[r]itualization may have both purposive and communicative properties . . . ."). The authors 
And many instrumental practices take on ceremonial qualities through repetition and association with particular practices. ${ }^{9}$ Following Moore, Myerhoff, and others, we will consider a practice ceremonial if it apparently conveys important symbolic meaning, even if it also serves some non-symbolic purpose: "The formal properties of ceremony are thus not sufficient to distinguish it from other cultural phenomena . . . It is in the area of meaning and effect that the distinction may be more clearly drawn . . .."10 Thus, the black robe worn by a judge may serve the purpose of identifying the role of a particular person who is one of many in a courtroom, but it does so through the use of a particular "sign" that is symbolic of her authority.

We thus consider the following practices as "ceremonial" in that they are symbols in the above sense:

- distinctive architectural features of the building in which the court is housed;

- distinctive decorative elements of the courtroom;

- distinctive furniture arrangement in the courtroom, such as a raised "bench" from which the judge or judges preside;

- distinctive apparel customarily worn by the judge (a robe or a wig);

- distinctive apparel customarily worn by the advocates;

- distinctive forms of address used when speaking to the judge;

- distinctive customary modes of deportment in the courtroom (such as rising when the judge enters).

By "distinctive" we mean that the practice is distinctive to courts and not otherwise generally found in the particular society examined. Put another way, it is a practice that signifies that the space is a "courtroom" and that the proceedings are judicial.

The ceremonial aspects of judicial proceedings in the U.S. and elsewhere are obvious. In the U.S. they include distinctive forms of dress, behavior, locution, and place. As a general rule, the higher the court in the judicial hierarchy, the more magnificent will be the space of the court and

frequently use "ritual" and "ceremony" interchangeably. See, e.g., id. at 8.

9. "Collective ceremony" has been characterized by its "formal properties," including, and especially relevant here: " 'Special behavior' or stylization: actions or symbols used are extra-ordinary themselves, or ordinary ones are used in an unusual way, a way that calls attention to them and sets them apart from other, mundane uses." Moore \& Myerhoff, supra note 8, at 7.

10. Id. at 8; see also Mary Gluckman \& Max Gluckman, On Drama, and Games and Athletic Contests, in SECULAR RITUALS, supra note 8, at 227, 233 (using Max Gluckman's term "ceremonial" to cover all highly conventionalized symbolic forms of action or speech which define social status, relationships, roles, etc.). 
the more stylized will be its processes.

In this study we examine only the impact of location and judicial attire. We consider those to be the most prominent features of courtroom ceremonial practices. Examination of other ceremonial attributes listed above, such as forms of address and physical deportment, would not have been practicable. Since our study did not involve video or audio recording of the processes and relied solely on reporting by the subjects as described below, we could not have sufficient confidence in subject recollection and assessment of verbal and physical behavior to use those as variables.

\section{THE HYPOTHESIS}

The Oral Argument Study tests the hypothesis that two variables, setting and judicial attire, have a positive effect on participant evaluation of judicial behavior as measured by widely accepted elements of process satisfaction. Analogous support for the hypothesized enhanced effect of judicial attire on participants is found in a recent study of physician attire in the U.S. ${ }^{11}$ Survey respondents were presented with pictures of male and female "doctors" in four different kinds of attire: normal business attire, "professional" attire (i.e., a white lab coat over business attire), surgical "scrubs," and casual attire. They were asked to choose among the doctors pictured for a variety of clinical purposes. Respondents "overwhelmingly" favored doctors in "professional" attire. They had greater trust and confidence in those doctors, were more willing to discuss intimate personal matters with them, and expressed a greater willingness to return to those doctors for follow-up treatment. Moreover, doctors dressed professionally were "positively associated with respondent commitment to adhere to prescribed therapy." $" 12$ The results are similar to those of other studies "conducted worldwide in a variety of settings." 13

The subjects of our study were first-year students at New York University (NYU) School of Law. This hypothesis invokes psychological studies of participant evaluation of process satisfaction. Investigations of the psychology of procedural justice support the propositions that are the central findings of that school: disputants can and do evaluate the fairness of processes independently of the fairness of outcomes and are "more satisfied with the outcomes they receive when they feel that court procedures are fair." 14 More complex issues are raised when we ask what characteristics of process lead to a favorable view of its fairness. Tyler

11. S.U. Rehman et al., What To Wear Today? Effect of Doctor's Attire on the Trust and Confidence of Patients, 118 AM. J. MED. 1279 (2005).

12. Id. at 1284 .

13. Id.

14. Tyler \& Lind, supra note 6 , at 71 ; THIBAULT \& WALKER, supra note 7 , at 80. 
and Lind, focusing on "group-value," have emphasized "the symbolic and psychological" implications of procedures for feelings of inclusion in society and for the belief that the institution using the procedure holds the person in high regard. ${ }^{15}$ They identify three litigant beliefs as "crucial to judgments of procedural justice." These are that authorities are trustworthy (a factor Tyler calls "trust"); that the participant is treated by authorities as a full-fledged member of society ("standing"); and that he or she is accorded evenhanded nondiscriminatory treatment ("neutrality"). ${ }^{16}$ In a subsequent article Tyler added a fourth "critical" factor, "voice in the decision making process," i.e., "people want to have an opportunity to state their case to legal authorities." 17 Tyler and Lind also argue that people use fairness process evaluations as a "heuristic" to decide whether they have been treated fairly, which then influences their decision to comply with the decision. ${ }^{18}$ Because most people are neither equipped nor have the time to make full and independent evaluations of the substantive outcome they receive, the fairness heuristic gives them a cognitive tool for assessing the process before learning the result. Under this theory, people look to behavioral cues-such as the level of respect, understanding, and attention they are receiving - to determine fairness of procedure.

Fairness heuristic theory argues that people use the factors they do to arrive at impressions of fairness because questions like respect, consideration, and neutrality are the sorts of things that people feel most comfortable in making judgments about. However irrational it might seem, at first glance, to use judgments of an authority's politeness or of a procedure's dignity to arrive at judgments of whether one is being treated fairly, these are social signs and symbols that people are comfortable interpreting. ${ }^{19}$

To bring this back to the current inquiry, judicial ceremony could reasonably be thought to contribute to both appearance of neutrality and perception of respect for the litigant. The judge's robe and the other ceremonial symbols of the courtroom are in this sense "social signs" that the judge has put aside her individuality and assumed the role of an authority acting "under law"-that is, deciding according to neutral principles. Further, the person who has been granted access to the elaborately staged process will arguably experience feelings of inclusion and respect. Alternatively, we can hypothesize that a participant-

15. Tyler \& Lind, supra note 6 , at 75 .

16. Id.

17. Tom R. Tyler, Does the American Public Accept the Rule of Law? The Findings of Psychological Research on Deference to Authority, 56 DEPAUL L. REV. 661, 664 (2007).

18. Tyler \& Lind, supra note 6 , at 77.

19. Id. at 80 . 
especially if not a repeat player-will feel disrespected and disinclined to trust the judge if the court in which he is heard does not measure up to expectations based on iconic images with which he is familiar. Tyler suggests that individuals are more likely to think a process just and fair, and are more likely to comply with the result, if they perceive the authorities as acting according to the rule of law. ${ }^{20}$ The robe and other regalia that are emblematic of the judicial process arguably add to the dignity of the setting and may serve as heuristics that signal the judge's commitment to the rule of law.

We note here that the value of our study is influenced by, but not dependent on, the procedural justice psychology findings cited above: it is useful to learn whether judicial ceremony affects participant evaluations regardless of the theoretical explanation for it.

To be sure, the work of Tyler, Lind, and other investigators of the psychology of procedural justice has not escaped criticism. Two themes are particularly relevant here. One concerns the limitations of the experimental methodology on which they have largely relied. ${ }^{21}$ As Chevigny observed, "[i]t seems likely, for example, that subjects, especially college or law students like those used in many of the experiments, might express a stronger preference for fair procedures in a setting where the outcome does not actually matter to them."22 That concern is relevant to our study as well, inasmuch as the subjects, firstyear law students, may have already been acculturated to value the ceremonial accoutrements of the judicial process more than the general population. However, Tyler's critics have generally concluded that his "key findings," having been supported by field studies, are "persuasive."23 And, contrary to the view of those critics, one could expect that law students, already trained in the legal requirements of effective and fair procedures, would be less influenced by "mere" ceremony than lay participants in the legal process. Since our methodology approximates that of prior researchers in this genre, we believe that, while our own conclusions cannot be willy-nilly applied to a more general population, our findings at the very least suggest more extensive future investigation, using field studies where possible.

A second theme sounded by critics of Tyler's work focuses on its arguable narrowness of scope and failure to appreciate its political

20. Tyler, supra note 17 , at 661 .

21. See Paul G. Chevigny, Fairness and Participation, 64 N.Y.U. L. REV. 1211 (1989) (book review); Valerie P. Hans, Judgments of Justice, 3 PSYCHOL. SCI. 218 (1992) (book review); Layla Skinns, Tyler, T.R., \& Huo, Y.J. (2002). Trust in the Law: Encouraging Public Cooperation with the Police and the Courts, 32 CRIM. JUST. REV. 456 (2007) (book review).

22. Chevigny, supra note 21 , at 1212 .

23. Hans, supra note 20, at 219; see also Chevigny, supra note 21 , at 1212 . 
implications. ${ }^{24}$ The finding that the propensity to accept authority when it is exercised through processes seen as fair, these critics claim, opens the door to manipulation and may lead to false consciousness. Thus, Tyler et al. can be faulted for failing to critically engage the power-legitimizing implications of their work. Since we do not in this Essay explore political implications, we are also subject to this critique. Nonetheless, we believe that empirical investigation into a practice as widely followed as judicial ceremony is valuable in itself. The critical analysis of these practices will, we hope, be furthered by our findings and is indeed one of our motivations.

\section{THE ORAL ARGUMENT STUDY}

\section{A. Survey Description}

First-year NYU School of Law students are required to participate in a moot court argument. In the years in which the study was conducted, the students were randomly assigned to argue for or against a motion for a preliminary injunction. Every student pair was assigned the same case and motion to argue. Although the class is graded on a pass/fail basis, faculty report that students took the exercise seriously and that many spent several weeks preparing their briefs and oral presentations.

The volunteer "judges" presiding over the argument may be law professors, local practitioners outside of the law faculty, or members of the judiciary. The argument may be held in a moot courtroom (which could be at a law firm office or at the law school), the courtroom of an actual sitting judge, or a conference room at a law firm or courthouse. Given the large number of arguments that must be accommodated, some disparity within the location categories is unavoidable. For example, a conference room at a large New York law firm is likely to be more imposing than that of a small firm or public interest organization. Similarly, some law firms made formal moot courtrooms available, while the moot courtrooms at the law school are multi-purpose rooms that are arranged as courtrooms on an ad hoc basis.

The oral argument presented a ready-made opportunity to study the effects of place and attire on this cohort by surveying participating students about their evaluation of fairness-related ingredients after the conclusion of the argument. The survey was constructed to investigate whether the type of venue in which the argument was held and/or the judge's attire (robe vs. business attire) affected the students' assessment

24. See Chevigny, supra note 20, at 122; Hans, supra note 21, at 219; Austin Sarat, Authority, Anxiety, and Procedural Justice: Moving from Scientific Detachment to Critical Engagement, 27 LAW \& SOC'Y REV. 647, 659 (1993) (book review); Skinns, supra note 21, at 457. 
of the dignity of the setting and of judicial behavior. The factors tested were those shown to be associated with participant satisfaction with an adjudicatory process: respectfulness, attentiveness, knowledge, the understanding of the decision-maker, and the dignity of the setting. ${ }^{25}$ The role of costume was introduced by requesting a random number of the presiding judges to wear judicial robes, while others were asked to preside in normal business attire. Judicial robes were provided to the persons who simulated judges for the exercise.

The study proceeded in two phases. In the first phase, a survey was administered by e-mail to all of the students who participated in the exercise in academic year 2007. In the second phase, conducted in the 2009 academic year, the same survey was administered only to those firstyear students in the 2009 cohort who presented their oral argument to a sitting judge in a real courtroom. All of the judges presiding in 2009 were asked to preside wearing business attire, not judicial robes. The purpose of the second phase survey was to obtain a sample of arguments conducted in real courtrooms before real judges who did not wear robes. That was desirable because all of the real judges who had presided in courtrooms in 2007 wore robes; the 2009 survey therefore allowed us to isolate the effect of robes from that of the courtroom. There is no reason to believe that the students in the 2009 sample would have non-random differences from the 2007 sample, because the oral argument was based on the same fact and law for both samples and because all students were assigned to their argument venues by the program administrators at random. We therefore combined the responses from the two samples in the analysis that follows. ${ }^{26}$

Students were asked by e-mail to complete an attached survey and return it by e-mail to the law school technology office, not to the investigators. Thus, students could be, and were, assured that their surveys would be anonymous to the investigators. They were asked to rate the judges on a five point scale for respectfulness, attentiveness, knowledge, and understanding, and to assess the dignity of the setting and the justness of the decision. As shown below, we then analyzed the relation between these ratings and the two variables of place and attire. We also investigated the impact of these factors on the student assessment of the substantive justness of the decision.

\section{B. Response Rates}

In the first phase we obtained responses from 265 of the 450 students to

25. See Tyler \& Lind, supra note 6, at 79-80.

26. We separately surveyed the judges who presided in 2007 for their evaluations of the students. The results of that survey will be addressed in a separate paper. 
whom the survey was distributed (i.e. all who completed the 2007 Lawyering course exercise). After excluding responses with errors and incomplete entries, we were left with 258 responses. Under the circumstances in which the survey was conducted, we conclude that that was an acceptable response rate. The survey was announced to students by an e-mail which asked them to participate by clicking on a link. They were informed that participation was anonymous, was completely voluntary, and was not an assignment of the course. As the oral advocacy exercise was the final assignment of the spring semester, students were preparing for final exams, and many may have regarded the survey participation as an undesirable use of their time. While we acknowledge that there may be a voluntary response bias in our survey results, we do not believe it to be particularly strong, given the relatively low kurtosis of the distribution of the survey responses. In other words, upon examining the survey date we saw that the responses were well distributed across a range of values as opposed to clustering in extreme values. In the second survey, we obtained twenty-nine responses from the thirty-two students to whom the survey had been distributed. (i.e. all of the students who had argued in courtrooms before real judges).

\section{Methodology}

The survey, which was identical in both phases, sought responses to twenty-five statements and invited respondents to add comments. For the purposes of this Essay, we focus on the following key statements:

Statement 9: The judge listened to my argument attentively.

(Responses coded as variable "attme.")

Statement 10: The judge listened to my opponent attentively.

(Responses coded as variable "attop.")

Statement 11: The judge understood the points I made during the argument.

(Responses coded as variable "underme.")

Statement 12: The judge understood the points my opponent made during the argument.

(Responses coded as variable "underop.")

Statement 13: The judge was knowledgeable about the legal issue involved in the case.

(Responses coded as variable "knowledge.")

Statement 14: The judge treated my argument with respect.

(Responses coded as variable "resme.")

Statement 15: The judge treated my opponent's argument with 
respect.

(Responses coded as variable "resop.")

Statement 16: The room in which the argument was held was dignified.

(Responses coded as variable "dignified.") ${ }^{27}$

Statement 19: The decision the judge announced, if any, was a just decision.

(Responses coded as variable "just.")

The respondent's agreement with each of these statements is measured on a five-point scale starting at one, representing strong disagreement, and rising to five, which denotes strong agreement. To test the hypothesis that place and costume affect an individual's evaluation of judicial function and behavior, we explore whether a statistical relationship exists between these measures of perceived fairness and variables that characterize location and costume. Specifically, respondents were asked to respond to the subsequent two questions:

Statement 20: What was the location of the argument?

Statement 21: During your argument, did the judge wear any clothing particular to the judicial role?

Respondents were instructed to indicate the kind of attire the judge wore if they answered yes to that question. All who did so reported that the judge wore a robe; some added that it was a black robe. ${ }^{28}$ The location of the proceedings fell into one of three categories: courtroom, moot courtroom, or conference room. ${ }^{29}$ According to our hypothesis, the ceremonial aspects of the proceeding in the form of costume and place will have a positive effect on participant evaluation of judicial behavior: a more formal location and the use of a judicial robe should be associated with higher levels of perceived judicial behavior and function. It is these hypotheses that form the basis of our statistical inquiry.

27. Students were randomly assigned to one of a courtroom, a moot courtroom, or a conference room.

28. The presence of judicial costume was measured using an indicator variable that takes value 1 when judicial attire is present and 0 when it is not.

29. In order to convert the location responses into numerical variables, we define two indicator variables. The first indicator variable takes value 1 if the proceedings were conducted in a courtroom and 0 otherwise. The second indicator variable takes value 1 if the proceedings were conducted in a conference room and 0 otherwise. The combination of these two variables provides a numerical indicator of the location of the proceedings. For instance, if both indicator variables take value 0 , then the location of the proceedings must be in a moot courtroom. 


\section{Effect of Variables}

\section{Perceived Room Dignity Enhanced Assessments of the Judge}

As a first step in our analysis we examine the correlation between our measures of judicial function ${ }^{30}$ and the perceived dignity of the room. ${ }^{31}$ In performing this analysis we must take into consideration that the values assigned to the observations have no intrinsic meaning or scale and are thus ordinal in nature as opposed to cardinal where the intervals measurements have a fixed intrinsic value. Rather, they merely represent an ordering of a respondent's agreement with a statement. Thus we cannot assume that to a respondent, the difference between a score of two or three is the same as the difference between a score of four or five. ${ }^{32}$ Tables One and Two list the computed rank correlations using two different measures to ensure the robustness of our result and the p-values associated with a null hypothesis that the coefficients are equal to zero. ${ }^{33}$ The results show that for every measure the rank correlation with perceived room dignity is positive and strongly significant. That means that the advocates who argued in surroundings they considered dignified tended to perceive judges as more attentive, understanding, knowledgeable, respectful, and just. Since correlations have no scale and are bounded between the values of -1 and 1 , what we can take from our results is that these statistical relationships are positive and statistically significant. ${ }^{34}$

\section{Factors Affecting the Dignity Assessment}

There are a variety of factors that might contribute to an individual's perception of room dignity. In order to better understand that effect, we control for two elements that we believe to be important determinants of room dignity-judicial costume and location. ${ }^{35}$ As further developed

30. Statements $9,10,11,12,13,14,15$, supra page 230 .

31. Statement 16, supra page 231.

32. Since the measurement intervals between the observed values cannot be assumed to be constant, standard measures such as Pearson's correlation coefficient and linear regression coefficients that presume the data to be cardinal are not appropriate and may lead to biased statistical results. Instead, we utilize non-parametric measures of correlation that only take into account ordinal information. The natural choices for such a metric are Spearman's rank correlation and Kendall's Tau, which are computed using the ranks of a given set of observations. See Appendix, infra page 241.

33. Tables 1 and 2. Again, we omit the standard Pearson's correlation, since it should only be applicable to cardinal data (where the intervals measurements have a fixed intrinsic value), while our data is ordinal in nature.

34. Due to the large number of observations in our data (over two hundred), large sample critical values were deemed to be good approximations for these two tests.

35. Since judicial costume and location are randomly assigned, we may simply partition the data set into responses falling into the different groups and conduct a statistical comparison. Again, parametric methods that presume cardinal measurements such as difference-of-means tests and 
below, we find that the use of a judicial robe enhances respondents' assessment of the judge's knowledge. Second, a courtroom was reported to be more dignified than either a moot courtroom or a conference room.

\section{The Effect of Robes}

Line One of Table Three compares the response rankings of all students arguing before a judge who wore a robe to those arguing before a judge who did not, regardless of location. ${ }^{36}$ Under the null hypothesis of the Mann-Whitney test, robes appear to have two strong effects upon a student advocate's survey response. According to the computed test statistics, we reject the null hypothesis at the five percent level of significance for the statements associated with perceived knowledge ${ }^{37}$ and the dignity of the room. ${ }^{38}$ Thus while the presence of a robe is indeed associated with higher levels of perceived room dignity and judicial knowledge, it had no statistically significant effect upon a respondent's perception of judicial attention, understanding, and respect. These results may be naively interpreted to conclude that judicial robes act to enhance an advocate's perception of room dignity. However, as we will show later, while the positive effect of robes upon perceived knowledge can be solely attributed to that attire, it is location that dictated the dignity effect.

\section{The Effect of Location}

We now turn our attention to the effect of location. Line 2 of Table 3 compares the response rankings of respondents who argued in a courtroom to those whose arguments took place in a conference room. The Mann-Whitney test statistics reveal a statistically significant strong positive effect of the courtroom setting (versus conference room) upon the response to the statement that the judge was respectful, ${ }^{39}$ and the dignity of the room. ${ }^{40}$ There was no statistically significant effect between the conference room and the courtroom upon perceptions of judicial attention to the respondent, the judge's understanding of the arguments of either advocate, the respect shown to the opposing advocate, and the knowledge displayed by the judge or the justice of the decision.

\footnotetext{
ANOVA are inapplicable due to the nature of our data. Instead, we conduct an ordinal comparison and apply the Mann-Whitney test of significance. See Appendix, infra page 241. That test is nonparametric in that it allows us to assess whether two independent samples are obtained from the same distribution without specifying or assuming the underlying distributional form. See Appendix, infra page 241 .

36. Table 3, at Line 1.

37. Statement 13, supra page 230.

38. Statement 16, supra page 231.

39. Statement 14, supra page 230.

40. Statement 16, supra page 231 .
} 
Similar results are obtained when the response rankings from arguments held in a courtroom are compared with those obtained from arguments held in a moot courtroom. ${ }^{41}$ Again the setting is perceived by respondents to be significantly more dignified than the moot courtroom, though the effect on perceived judicial respect did not appear.

A comparison of the response rankings arising from arguments held in a conference room against those held in a moot courtroom yields no statistically significant differences except from that associated with perceived dignity. ${ }^{42}$ That is, respondents perceived conference rooms to be more dignified than moot courtrooms. The latter finding reflects the reality that the moot courtrooms used for the exercise were reconfigured class rooms whereas virtually all of the conference rooms were wellappointed rooms in large law firms. Apart from that, the two locations produce no statistically significant different responses.

The above three comparisons reveal that the setting in which the argument was held affected the respondents' evaluation of some dependent variables. Courtrooms were perceived to be the most dignified followed by the conference rooms with the moot courtrooms being the least dignified. Moreover, respondents who argued in courtrooms perceived judges to be more respectful than respondents who argued in conference rooms.

\section{The Interaction Between Robes and Location}

We will now proceed to analyze the effect of robes within the three different locations. Line Five of Table Three compares the responses of those who argued in a courtroom before a judge in a robe with those who argued in a courtroom before a judge who presided in normal business attire. ${ }^{43}$ The comparisons in Line Five reveal that respondents who argued in courtrooms before a judge in robes perceived the judges to be more knowledgeable than did those who argued before judges without robes. What is also of interest is the fact that robes had no effect upon the perceived dignity of the locations.

Lines Six and Seven show the same effect when the argument took place in moot courtrooms and conference rooms, with those arguing before judges in robes reporting a higher perceived level of knowledge than those in business attire. ${ }^{44}$ The consistency of that effect across all three locations gives strong evidence of a positive role of robes in a crucial aspect of perceived judicial function (i.e. the judge's knowledge of

\footnotetext{
41. Table 3, at Line 3 .

42. Id. at Line 4.

43. Id. at Line 5.

44. Id. at Lines 6-7
} 
the issue being argued). That result is consistent with the findings of Rehman et al. to the extent that appropriate professional attire has a favorable effect upon perceived competence of a medical professional. ${ }^{45}$

\section{Effect of Location: Arguing Before a Robed Judge}

Next, we report the effect of location after controlling for robes, the results of which are reported in Line Eight through Line Thirteen of Table Three. ${ }^{46}$ First, we restrict our attention to responses from advocates who argued before a judge in robes. ${ }^{47}$ Comparing the responses of advocates who argued in conference rooms to those in courtrooms we find two statistically significant effects. First, advocates perceived robed judges to be more respectful in a courtroom setting and, as to be expected, courtrooms were found to be more dignified than conference rooms. ${ }^{48}$ Second, those who argued in courtrooms found their surroundings to be more dignified than those arguing in moot courtrooms, though there was no statistically significant effect on respect. ${ }^{49}$ Comparing advocates arguing before robed judges in conference rooms with those in moot courtrooms, ${ }^{50}$ we found marginal statistical evidence (i.e. statistical significance at the ten percent level in a two-tailed test and at the five percent level in a one-tailed test) of advocates in conference rooms perceiving judges to be more respectful compared to those arguing in moot courtrooms. We can see from these results that the differences in the surroundings, in large, affected the perception of respect and dignity.

\section{Effect of Location: Arguing Before a Judge in Business Attire}

When we restrict our attention to advocates arguing before judges in business attire (i.e. without robes) and compare the responses from those arguing in courtrooms to those in conference rooms, we notice several significant effects. Line Eleven in Table Three reveals that advocates in courtrooms perceived those judges to be more attentive and knowledgeable (these results are marginally statistically significant) than those in conference rooms. ${ }^{51}$ Also, consistent with previous results, the dignity of the courtrooms was perceived to be strongly statistically higher than that of the conference rooms.

Comparing advocates arguing in courtrooms to those in moot

\footnotetext{
45. See Rehman et al, supra note 11.

46. Table 3, at Lines 8-13.

47. Id. at Lines 8-10.

48. Id. at Line 8 .

49. Id. at Line 9.

50. Id. at Line 10.

51. Id. at Line 11.
} 
courtrooms $^{52}$ and those arguing in conference rooms to those in moot courtrooms, ${ }^{53}$ we obtain somewhat similar results. Advocates appearing before judges wearing business attire and presiding in courtrooms perceived the location to be more dignified than other locations, but perceived no other differences.

\section{SUMMARY OF FINDINGS AND DISCUSSION}

We began our investigation by looking at the rank correlations between a measure of a student advocate's perception of the dignity of the location and a range of variables measuring perceived judicial behavior. Using two different measures of rank correlations, we found them to be positive and statistically significant for all our variables of interest. Thus we have a general finding that perceptions of room dignity and assessments of judicial behavior are positively related. That is an important finding for two reasons. First, procedural dignity has been found to be part of the heuristic by which ordinary people judge the fairness of court proceedings. ${ }^{54} \mathrm{~A}$ dignified setting may be taken as a signal that the participant is being treated respectfully. Second, if replicated in other studies, it should influence courtroom design as well as judges' choices of venues for hearing motions and other proceedings. Motivated by that, we proceeded to control for two elements that we posit to be important determinants of room dignity-judicial costume and location. Taking the aggregate data we first compared the response rankings of students arguing before a judge who wore a robe to those arguing before a judge who did not, regardless of location. We found that those arguing before judges in robes perceived the room to be more dignified and the judges to be more knowledgeable. As mentioned previously, taking that result at face value ignores the possible interaction between the effect of the robe and the location. We then partitioned the data by location and compared pair-wise the response rankings between those arguing in courtrooms, conference rooms, and moot courtrooms. Our results revealed a strong location effect, as courtrooms were perceived to be more dignified than both conference rooms and moot courtrooms and conference rooms were perceived to be more dignified than moot courtrooms. Moreover, those arguing in courtrooms perceived the judge to be more respectful compared to those in conference rooms. No further statistical differences were found in the response rankings when we compared observations from conference rooms with those in moot courtrooms.

52. Id. at Line 12.

53. Id. at Line 13.

54. See Tyler \& Lind, supra note 6 , at 80 . 
Since the robe was found to have the effect of making a room more dignified and the judge appear more knowledgeable when we considered the aggregated data, we attempted to disentangle the effects of both robes and location. To do so, we first analyzed the effect of robes within specific locations.

Limiting our attention to responses from those arguing before judges by location, our results revealed that those arguing before a judge who wore robes perceived the judge to be more knowledgeable than those arguing before a judge in business attire. The consistency of that result across all three locations indicates that, at least for this sample, the judicial robe promotes a positive view of the judge, regardless of the location of the legal proceeding studied. Recall that the relevant survey question asked the students to indicate the degree of their agreement with the statement that "the judge was knowledgeable about the legal issue involved in the case." ${ }^{\text {"55 }}$ Because of the controversy regarding the desirability of robes, we believe this to be one of our most interesting and important findings. We may assume that judges who are knowledgeable about the issue before them are preferred to those less knowledgeable. Jerome Frank, whose critical view of the robe we discussed above, allowed that the robe might increase respect for the judge. Our study lends support for that view and therefore arguably undercuts Frank's emphatically negative position. It should be noted that our finding is consistent with the previouslyreferenced study of the effect of attire on patient evaluation of physicians.$^{56}$ Nonetheless, one cannot rule out the possible effect of the robe on the judge. It is possible that the expectation of presiding in a robe, and therefore acting as a "symbol" of the justice system, incentivizes the judge to take the case more seriously and that robed judges are therefore more likely to actually be more knowledgeable about the issues presented. This Essay does not address the effect of attire on the judge's knowledge of the issues presented by the moot court argument. We could not make an accurate assessment of the judges' knowledge with the tools available to us, i.e. student reporting. Nor do we think that a judge's selfassessment of her degree of knowledge would have been sufficiently reliable to use as a variable. Our intuition is that it is unlikely that a lawyer, law professor, or judge preparing to preside over a moot court argument would be much affected by their prospective attire. In any event, even assuming that the student assessment of knowledge was influenced by the judge's actual displayed knowledge, our finding that robes "matter" remains important.

Frank might have responded to our finding by noting that the student

55. Statement 13, supra page 230.

56. Rehman et al., supra note 11 , passim. 
advocates made subjective judgments about the judges' knowledge of the issues and that the robe may have led them to mistaken and in any case unwarranted conclusions. Indeed, Frank might have turned our finding against the robe precisely because of its potentially misleading effect. Like the "procedural fairness effect" found by Lind, Tyler, and others, ${ }^{57}$ judicial ceremony may promote false confidence in the justice system. Of course, if contrary to our intuition the robe in fact incentivizes the judge to be better prepared, the student assessments would be accurate and the ensuing confidence in the judge would be well-placed. If the student assessment of judicial knowledge is solely or primarily a result of judicial attire the problem of false consciousness does arise. The normative issue thus raised is beyond the scope of this Essay but we note that public respect for the judicial process is generally considered desirable.

For completeness we then controlled for attire and compared the responses of student advocates in different locations. First restricting our attention to responses from advocates arguing before a judge in robes, our results revealed that those arguing in courtrooms found judges to be more respectful relative to those arguing in conference rooms, and that courtrooms were perceived to be statistically strongly more dignified than conference rooms. That strong dignity effect is consistent with the results of our prior comparison of courtroom and conference room responses. When again restricting our attention to responses from advocates arguing before a judge in robes and comparing the responses from students arguing in courtrooms to those arguing in moot courtrooms, we found no statistical differences in assessment of judicial function. The only statistically significant effects we found when performing these comparisons were that courtrooms were perceived to be more dignified than moot courtrooms and conference rooms, which again highlights the expected strong location effect of the room on perceived dignity. When we compare the responses of those arguing before judges in robes in conference rooms to those in moot courtrooms, we find marginal evidence of those arguing in conference rooms being accorded a higher level of respect but no difference in the dignity of the room. In other words, advocates arguing before judges in robes in a conference room setting found the location to be as dignified as those arguing before robed judges in moot courtrooms. The evidence of greater perceived judicial respect in courtrooms compared to conference rooms and between conference rooms and moot courtrooms serves to highlight the interaction or interplay between the effects of judicial attire and different settings. We can theorize that the combination of robe and dignity of the room

57. Lind et al., supra note 5, at 61-66. 
contributes to a positive evaluation of respect because the two elements combine to enhance the sense of status of the student advocate.

We also focused our attention on responses from advocates arguing before judges in business attire and compared the response rankings between our three locations. Without robes, the location effect is less pronounced, with marginal statistical evidence showing that advocates arguing in courtrooms perceived judges to be more attentive and knowledgeable when compared to those arguing in conference rooms. There was also strong evidence of greater perceived room dignity. No differences were found when we compared observations between moot courtrooms and courtrooms, or between conference rooms and moot courtrooms, except that the conference rooms and courtrooms were again found to be more dignified than moot courtrooms.

Notably, we found that the variable just, which reflected the student's assessment of the justice of the judge's decision (if a decision was announced) was not a statistically significant variable in any of our tests involving comparisons of location and costume (i.e. the assessment of the decision on the merits was not influenced by setting or judicial costume). However, when we partitioned the data by comparing those whose side the decision favored with those on the losing side we found strong evidence that the victorious advocates were more likely to believe the decision to be just. The "victors" also reported a far more positive assessment of judicial behavior than did the "losers." The former group found that the judge had exhibited greater attentiveness, respect, understanding, and knowledge. These results are intuitively sensible and are in general consistent with those prior investigations of the psychology of procedural justice. Those investigations have found that a favorable substantive result correlates with a positive assessment of the process, even though procedural fairness factors also contribute to it. ${ }^{58}$ The consistency of our results with prior studies on this aspect lends credence to our empirical technique and findings. Judicial ceremony may be one of the heuristics that participants use in evaluating the process by priming them to credit the bona fides of the judge.

\section{CONCLUSION}

We believe that our study shows that setting and judicial attire can and do affect the evaluation of judicial behavior by student advocates and that, in general, the use of culturally appropriate ceremonial aspects enhanced their evaluation of the judicial process. Of course, one must be cautious about generalizing from the student sample. First-year law students are

58. See id. at $970-71,975$. 
distinct in various ways from the general population of litigants and other participants in litigation. The pursuance of a law degree arguably suggests in itself some degree of acceptance of the legitimacy of the litigation process and its "signs." Second, the first year of law school may well have primed students to be more respectful of the judicial process than they would be otherwise. On the other hand, spending the better part of a year analyzing cases (and often hearing a critical professorial view) might be expected to arm students against the influence of judicial ceremony. Moreover, law students may be useful proxies for one major cohort of litigation consumers: practicing attorneys. In any event, despite these limitations, our results strongly suggest that judicial costume and setting do account for differences in perceptions of procedural fairness. Further research on the effects of judicial ceremony using different samples and settings is strongly recommended. 


\section{APPENDIX}

\section{SPEARMAN'S RANK CORRELATION}

To compute Spearman's rank correlation $\rho$ we let and denote the ranks assigned to observations and respectively, is defined as

$$
\rho=\frac{\sum_{i=1}^{n} R\left(x_{i}\right) R\left(y_{i}\right)-n\left(\frac{n+1}{2}\right)^{2}}{\sqrt{\sum_{i=1}^{n} R\left(x_{i}\right)^{2}-n\left(\frac{n+1}{2}\right)^{2}} \sqrt{\sum_{i=1}^{n} R\left(y_{i}\right)^{2}-n\left(\frac{n+1}{2}\right)^{2}}}
$$

To compute the above object we merely have to replace the observations in our data set with their ranks and compute Pearson's correlation coefficient on the ranks. Spearman's rank correlation may therefore be thought of as a special case of Pearson's correlation coefficient and is interpreted in the same way with positive values indicating a tendency for high values of one variable to be paired with high values of the other.

If no relationship should exist between room dignity and our measures of judicial function, our computed rank correlations should not be statistically different from zero. If we reject this hypothesis, we can conclude that dignified surroundings are related to perceptions of judicial function and behavior. For large samples, critical values to determine significance are well approximated by a standard normal distribution.

\section{KENDALL'S TAU}

To compute Kendall's Tau, $\tau$ let $(\mathrm{x} 1, \mathrm{y} 1),(\mathrm{x} 2, \mathrm{y} 2), \ldots,(\mathrm{xn}, \mathrm{yn})$ be a set of joint observations from two random variables $\mathrm{X}$ and $\mathrm{Y}$ respectively, such that all the values of (xi) and (yi) are unique. Any pair of observations (xi, yi) and (xj, yj) are said to be concordant if the ranks for both elements agree: that is, if both $x i>x j$ and $y i>y j$ or if both $x i<x j$ and $y i<y j$. They are said to be discordant, if $x i>x j$ and $y i<y j$ or if $x i<$ $x j$ and $y i>y j$. If $x i=x j$ or $y i=y j$, the pair is neither concordant, nor disconcordant.

$$
\tau=\frac{\text { (number of concordant pairs }- \text { number of discordant pairs }}{\frac{1}{2} n(n-1)}
$$

If the agreement between the two rankings is perfect (i.e., the two rankings are the same) the coefficient has value 1 while if the disagreement between the two rankings is perfect (i.e., one ranking is the 
reverse of the other) the coefficient has value -1 . Should the two variables be independent then we would expect the coefficient to be approximately zero. For large samples critical values are well approximated by normal distribution with mean 0 and variance $\frac{2(2 n+5)}{9 n(n-1)}$.

\section{THE MANN-WHITNEY TEST}

Assume that two random samples $\left\{x_{1}, x_{2}, \ldots, x_{n}\right\},\left\{y_{1}, y_{2}, \ldots, y_{m}\right\}_{\text {drawn }}$ from distributions $F()$ and $G()$ respectively, are said to be obtained from the same population if and only if $F()$ is precisely equal to $G()$. The Mann Whitney test therefore has as its null hypothesis:

$$
H_{0}: F(X)=G(X)
$$

One can also think of the Mann Whitney procedure as testing the null hypothesis that the probability of an observation from one population exceeding an observation from the second population to be precisely 0.5 . Intuitively, under the null hypothesis, if one were to combine observations from both samples into a single ordered sample and assign ranks from the smallest value to the largest, the sum of the ranks assigned to the values from one sample should not differ greatly to the sum of ranks assigned to the other. It follows that the null hypothesis may be rejected if the ranks associated with one sample tend to be larger than those of the other sample. If there are little or no ties in the data, the associated test statistic is computed as the sum of the ranks assigned to one sample. Letting denote the rank assigned to observation the test statistic is defined as

$$
T=\sum_{i=1}^{n} R_{i}
$$

If there are many ties, as is the case in our data, an alternative form of the test statistic is used

$$
\tilde{T}=\frac{T-n \frac{N+1}{2}}{\sqrt{\frac{n m}{N(N-1)} \sum_{i=1}^{n} R_{i}^{2}-\frac{n m(N+1)^{2}}{4(N-1)}}}
$$

Where $\sum_{i=1}^{n} R_{i}^{2}$ refers to the sum of squares of the average ranks used in both samples and $N=n+m$. For sample sizes above 20 the test 
statistic is well approximated by a standard normal random variable.

Table A-1:

Spearman's Rank Correlations Between

Dignity and Judicial Behavior

\begin{tabular}{c|c|c} 
VARIABLE & $\rho$ & P-VALUE \\
\hline Attme & 0.349 & 0.000 \\
Atop & 0.262 & 0.000 \\
Underme & 0.270 & 0.000 \\
Underop & 0.251 & 0.000 \\
Knowledge & 0.407 & 0.000 \\
Resme & 0.427 & 0.000 \\
Resop & 0.340 & 0.000 \\
Just & 0.199 & 0.006
\end{tabular}

Table A-2:

Kendall's Tau Between Dignity and Judicial Behavior

\begin{tabular}{c|c|c} 
VARIABLE & $\tau$ & P-VALUE \\
\hline Attme & 0.310 & 0.000 \\
Atop & 0.234 & 0.000 \\
Underme & 0.236 & 0.000 \\
Underop & 0.220 & 0.000 \\
Knowledge & 0.355 & 0.000 \\
Resme & 0.381 & 0.000 \\
Resop & 0.304 & 0.000 \\
Just & 0.164 & 0.008
\end{tabular}


Table A-3:Mann Whitney Test Results

\begin{tabular}{|c|c|c|c|c|c|}
\hline & Comparison & attme & attop & underme & underop \\
\hline 1 & Robe vs. No Robe & $\begin{array}{c}0.3667 \\
{[-0.9026]}\end{array}$ & $\begin{array}{c}0.1898 \\
{[-1.3111]}\end{array}$ & $\begin{array}{c}0.6617 \\
{[-0.4376]}\end{array}$ & $\begin{array}{c}0.2182 \\
{[-1.2313]}\end{array}$ \\
\hline 2 & $\begin{array}{l}\text { Court Room vs. Conf. } \\
\text { Room }\end{array}$ & $\begin{array}{r}0.1639 \\
{[1.3922]} \\
\end{array}$ & $\begin{array}{r}0.9728 \\
{[-0.0341]} \\
\end{array}$ & $\begin{array}{c}0.7688 \\
{[0.2940]}\end{array}$ & $\begin{array}{c}0.4946 \\
{[-0.6830]}\end{array}$ \\
\hline 3 & $\begin{array}{l}\text { Court Room vs. Moot } \\
\text { Court Room }\end{array}$ & $\begin{array}{c}0.3560 \\
{[-0.9231]}\end{array}$ & $\begin{array}{c}0.8493 \\
{[-0.1901]}\end{array}$ & $\begin{array}{c}0.4561 \\
{[-0.7452]}\end{array}$ & $\begin{array}{c}0.5460 \\
{[0.6038]}\end{array}$ \\
\hline 4 & $\begin{array}{l}\text { Conf. Room vs. Moot } \\
\text { Court Room }\end{array}$ & $\begin{array}{c}0.8586 \\
{[0.1782]} \\
\end{array}$ & $\begin{array}{c}0.7649 \\
{[-0.2990]}\end{array}$ & $\begin{array}{c}0.5548 \\
{[-0.5905]}\end{array}$ & $\begin{array}{c}0.9493 \\
{[0.0636]}\end{array}$ \\
\hline 5 & $\begin{array}{l}\text { Court Room: Robe vs. } \\
\text { No Robe }\end{array}$ & $\begin{array}{c}0.2673 \\
{[1.1092]} \\
\end{array}$ & $\begin{array}{c}0.3381 \\
{[0.9579]} \\
\end{array}$ & $\begin{array}{c}0.9119 \\
{[0.1106]}\end{array}$ & $\begin{array}{c}0.3752 \\
{[0.8868]}\end{array}$ \\
\hline 6 & $\begin{array}{l}\text { Conf. Room: Robe vs. } \\
\text { No Robe }\end{array}$ & $\begin{array}{c}0.2007 \\
{[-1.2797]}\end{array}$ & $\begin{array}{c}0.4920 \\
{[-0.6871]}\end{array}$ & $\begin{array}{c}0.1686 \\
{[-1.3767]}\end{array}$ & $\begin{array}{c}0.0545 \\
{[-1.9228]}\end{array}$ \\
\hline 7 & $\begin{array}{l}\text { Moot Court Room: } \\
\text { Robe vs. No Robe }\end{array}$ & $\begin{array}{c}0.9569 \\
{[-0.0540]} \\
\end{array}$ & $\begin{array}{c}0.5090 \\
{[-0.6604]}\end{array}$ & $\begin{array}{c}0.3868 \\
{[0.8654]}\end{array}$ & $\begin{array}{c}0.2301 \\
{[1.2002]}\end{array}$ \\
\hline 8 & $\begin{array}{l}\text { Robe: Court Room vs. } \\
\text { Conf. Room }\end{array}$ & $\begin{array}{c}0.3418 \\
{[-0.9507]}\end{array}$ & $\begin{array}{c}0.9766 \\
{[0.0294]}\end{array}$ & $\begin{array}{c}0.2592 \\
{[-1.1283]}\end{array}$ & $\begin{array}{c}0.5919 \\
{[-0.5360]}\end{array}$ \\
\hline 9 & $\begin{array}{l}\text { Robe: Court Room vs. } \\
\text { Moot Court Room }\end{array}$ & $\begin{array}{c}0.9401 \\
{[-0.0751]}\end{array}$ & $\begin{array}{c}0.9852 \\
{[-0.0186]}\end{array}$ & $\begin{array}{c}0.9547 \\
{[0.0568]}\end{array}$ & $\begin{array}{c}0.1657 \\
{[1.3863]}\end{array}$ \\
\hline 10 & $\begin{array}{l}\text { Robe: Conf. Room vs. } \\
\text { Moot Court Room }\end{array}$ & $\begin{array}{c}0.3802 \\
{[-0.8776]}\end{array}$ & $\begin{array}{c}0.9074 \\
{[0.1163]}\end{array}$ & $\begin{array}{c}0.2752 \\
{[-1.0913]} \\
\end{array}$ & $\begin{array}{c}0.0402 \\
{[-2.0518]}\end{array}$ \\
\hline 11 & $\begin{array}{l}\text { No Robe: Court Room } \\
\text { vs. Conf. Room }\end{array}$ & $\begin{array}{c}0.0812 \\
{[1.7438]}\end{array}$ & $\begin{array}{c}0.5557 \\
{[0.5892]}\end{array}$ & $\begin{array}{c}0.9261 \\
{[0.0927]}\end{array}$ & $\begin{array}{c}0.8253 \\
{[-0.2207]}\end{array}$ \\
\hline 12 & $\begin{array}{l}\text { No Robe: Court Room } \\
\text { vs. Moot Court Room }\end{array}$ & $\begin{array}{r}0.1754 \\
{[-1.3552]} \\
\end{array}$ & $\begin{array}{c}0.6672 \\
{[-0.4301]}\end{array}$ & $\begin{array}{c}0.3164 \\
{[-1.0018]}\end{array}$ & $\begin{array}{c}0.5906 \\
{[-0.5380]}\end{array}$ \\
\hline 13 & $\begin{array}{l}\text { No Robe: Conf. Room } \\
\text { vs. Moot Court Room }\end{array}$ & $\begin{array}{c}1.0000 \\
{[0.0000]}\end{array}$ & $\begin{array}{c}0.9576 \\
{[0.0532]}\end{array}$ & $\begin{array}{c}0.2478 \\
{[-1.1558]}\end{array}$ & $\begin{array}{c}0.3612 \\
{[-0.9131]}\end{array}$ \\
\hline 14 & Favor vs. Not in Favor & $\begin{array}{c}0.0339 \\
{[2.1212]}\end{array}$ & $\begin{array}{c}0.2217 \\
{[-1.2221]}\end{array}$ & $\begin{array}{c}8.16 \mathrm{E}-04 \\
{[3.3472]}\end{array}$ & $\begin{array}{c}0.0440 \\
{[2.0137]}\end{array}$ \\
\hline
\end{tabular}

Note [a]: Statistical comparisons of variables attme, attop, underme, underop, knowledge, resme, resop and dignity for line 1-13 were performed using 287 observations. The just variable comparisons for all 14 lines were performed using 174 observations since not all judgments were reported. Also, line 14 comparisons utilized 174 observations.

Note [b]: Statistically significant results at the $5 \%$ level for a two-sided test are marked as bold while results which are statistically significant at the $10 \%$ for a two-sided test or $5 \%$ for a one-sided test are marked as bold and italicized.

Note [c]: Values reported in the table represent the Mann Whitney U-Test statistics while the values located directly below in parentheses are the associated $z$-values. 


\begin{tabular}{|c|c|c|c|c|c|}
\hline knowledge & resme & resop & dignified & just & \\
\hline $\begin{array}{c}2.62 \mathrm{E}-12 \\
{[6.9967]}\end{array}$ & $\begin{array}{c}0.9986 \\
{[-0.0018]}\end{array}$ & $\begin{array}{c}0.3632 \\
{[-0.9092]}\end{array}$ & $\begin{array}{c}0.0171 \\
{[2.3837]}\end{array}$ & $\begin{array}{c}0.3107 \\
{[-1.0138]}\end{array}$ & 1 \\
\hline $\begin{array}{c}0.2330 \\
{[1.1926]}\end{array}$ & $\begin{array}{c}0.0193 \\
{[2.3387]}\end{array}$ & $\begin{array}{c}0.4192 \\
{[0.8077]}\end{array}$ & $\begin{array}{l}5.69 \mathrm{E}-11 \\
{[6.5517]}\end{array}$ & $\begin{array}{c}0.8675 \\
{[-0.1668]}\end{array}$ & 2 \\
\hline $\begin{array}{c}0.9749 \\
{[-0.3170]}\end{array}$ & $\begin{array}{c}0.1534 \\
{[-1.4275]}\end{array}$ & $\begin{array}{c}0.7148 \\
{[-0.3654]}\end{array}$ & $\begin{array}{c}1.81 \mathrm{E}-13 \\
{[7.3621]}\end{array}$ & $\begin{array}{c}0.6939 \\
{[-0.3935]}\end{array}$ & 3 \\
\hline $\begin{array}{c}1.1821 \\
{[0.1160]}\end{array}$ & $\begin{array}{c}0.5326 \\
{[0.6240]}\end{array}$ & $\begin{array}{c}0.7347 \\
{[0.3389]}\end{array}$ & $\begin{array}{r}3.56 \mathrm{E}-04 \\
{[3.5710]}\end{array}$ & $\begin{array}{c}-0.7730 \\
{[-0.7730]}\end{array}$ & 4 \\
\hline $\begin{array}{c}2.02 E-04 \\
{[3.7168]}\end{array}$ & $\begin{array}{c}0.9178 \\
{[-0.1032]}\end{array}$ & $\begin{array}{c}0.2291 \\
{[1.2027]}\end{array}$ & $\begin{array}{c}0.9709 \\
{[-0.0365]}\end{array}$ & $\begin{array}{c}0.9671 \\
{[-0.0413]}\end{array}$ & 5 \\
\hline $\begin{array}{c}1.44 \mathrm{E}-05 \\
{[4.3381]}\end{array}$ & $\begin{array}{c}0.2151 \\
{[-1.2398]}\end{array}$ & $\begin{array}{c}0.6109 \\
{[-0.5088]}\end{array}$ & $\begin{array}{c}0.7830 \\
{[0.2754]}\end{array}$ & $\begin{array}{c}0.2489 \\
{[-1.1530]}\end{array}$ & 6 \\
\hline $\begin{array}{c}2.58 E-04 \\
{[3.6544]}\end{array}$ & $\begin{array}{c}0.1823 \\
{[1.3337]}\end{array}$ & $\begin{array}{c}0.5467 \\
{[-0.6027]}\end{array}$ & $\begin{array}{c}0.1400 \\
{[1.4756]}\end{array}$ & $\begin{array}{c}0.7914 \\
{[-0.2645]}\end{array}$ & 7 \\
\hline $\begin{array}{c}0.3210 \\
{[0.9924]}\end{array}$ & $\left.\begin{array}{c}0.0373 \\
{[2.0825}\end{array}\right]$ & $\begin{array}{c}0.8064 \\
{[-0.2451]}\end{array}$ & $\begin{array}{l}4.46 \mathrm{E}-04 \\
{[3.5113]}\end{array}$ & $\begin{array}{c}0.6228 \\
{[-0.4919]}\end{array}$ & 8 \\
\hline $\begin{array}{c}0.5109 \\
{[0.6574]}\end{array}$ & $\begin{array}{c}0.7159 \\
{[-0.3639]} \\
\end{array}$ & $\begin{array}{c}0.9773 \\
{[-0.0285]} \\
\end{array}$ & $\begin{array}{l}8.23 E-06 \\
{[4.4591]}\end{array}$ & $\begin{array}{c}0.7583 \\
{[-0.3077]}\end{array}$ & 9 \\
\hline $\begin{array}{c}0.7489 \\
{[0.3201]}\end{array}$ & $\begin{array}{c}0.0911 \\
{[1.6897]}\end{array}$ & $\begin{array}{c}0.8508 \\
{[-0.1881]}\end{array}$ & $\begin{array}{c}0.1863 \\
{[1.3218]}\end{array}$ & $\begin{array}{c}0.8126 \\
{[-0.2371]}\end{array}$ & 10 \\
\hline $\begin{array}{c}0.0856 \\
{[1.7192]} \\
\end{array}$ & $\begin{array}{c}0.7162 \\
{[0.3635]}\end{array}$ & $\begin{array}{c}0.1710 \\
{[1.3690]}\end{array}$ & $\begin{array}{l}2.39 \mathrm{E}-06 \\
{[4.7176]}\end{array}$ & $\begin{array}{c}0.8446 \\
{[-0.1960]}\end{array}$ & 11 \\
\hline $\begin{array}{c}0.5453 \\
{[0.6048]}\end{array}$ & $\begin{array}{c}0.4535 \\
{[-0.7496]}\end{array}$ & $\begin{array}{c}0.5003 \\
{[-0.6739]}\end{array}$ & $\begin{array}{l}1.27 \mathrm{E}-08 \\
{[5.6907]}\end{array}$ & $\begin{array}{c}0.7839 \\
{[0.2742]}\end{array}$ & 12 \\
\hline $\begin{array}{c}0.3669 \\
{[-0.9022]}\end{array}$ & $\begin{array}{c}0.4316 \\
{[-0.7865]}\end{array}$ & $\begin{array}{c}0.5812 \\
{[0.5516]}\end{array}$ & $\begin{array}{c}3.28 E-04 \\
{[3.5924]}\end{array}$ & $\begin{array}{c}0.4985 \\
{[-0.6769]}\end{array}$ & 13 \\
\hline $\begin{array}{c}0.0544 \\
{[1.9735]}\end{array}$ & $\begin{array}{c}4.41 E-04 \\
{[3.5143]}\end{array}$ & $\begin{array}{c}0.0272 \\
{[2.2085]}\end{array}$ & $\begin{array}{c}0.7453 \\
{[-0.3249]}\end{array}$ & $\begin{array}{c}3.43 \mathrm{E}-14 \\
{[7.5810]}\end{array}$ & 14 \\
\hline
\end{tabular}


